\title{
A vaginal CSF leak
}

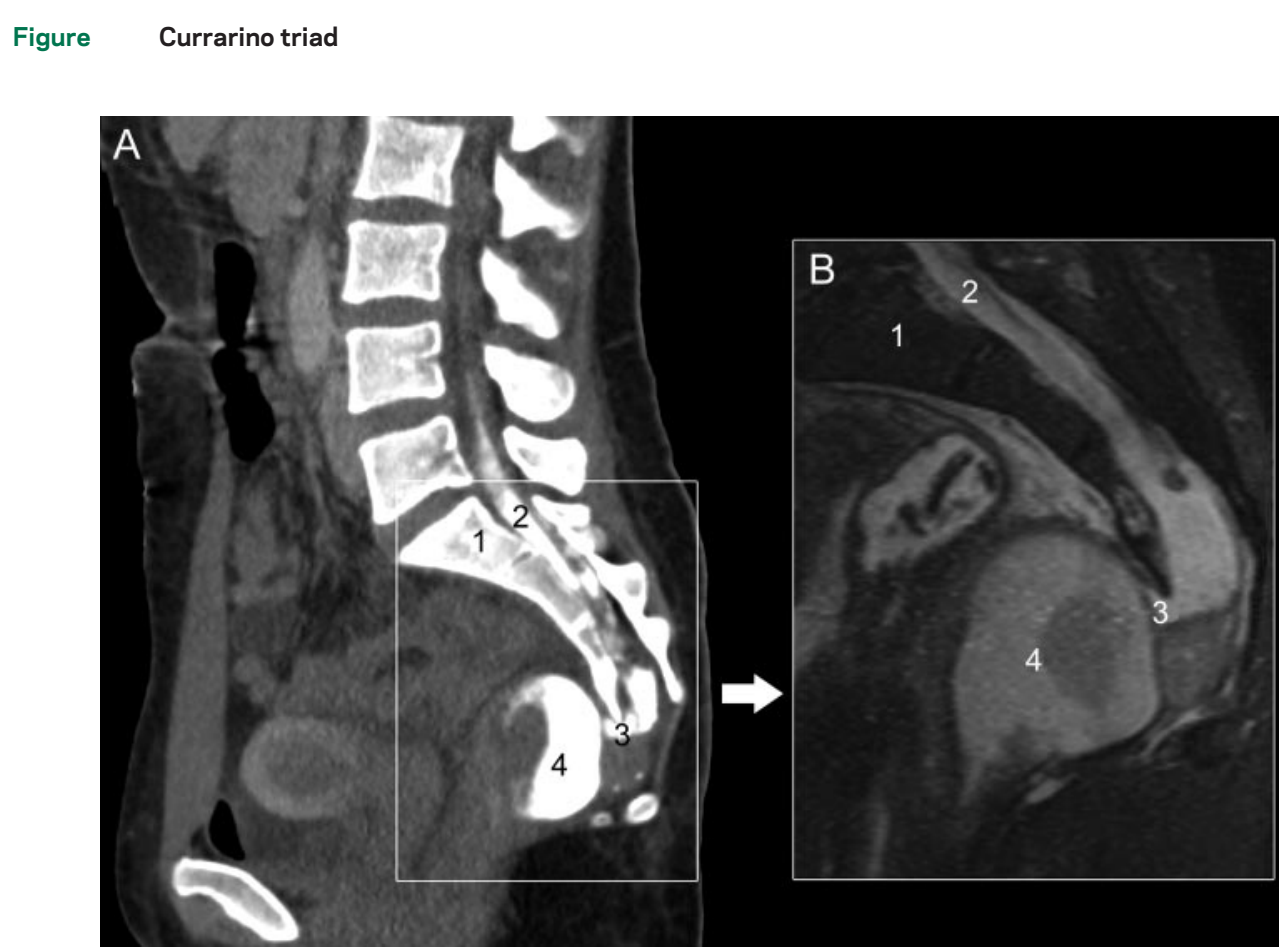

(A) CT scan: following retrograde injection, contrast is tracking up the spinal canal. (B) MRI scan: the ventral sacral meningocele and anterior sacral defect are clearly shown. 1 = sacrum; 2 = thecal sac; $3=$ sacral defect; $4=$ meningocele.

A 26-year-old woman presented to her gynecologist with persistent clear vaginal fluid loss for 2 months, accompanied by symptoms of headache and vertigo. Subsequently, she developed tenesmus. Surgical exploration revealed a duplicated anus and a presacral mass draining clear fluid containing white particles. In the following hours the patient developed a fulminant meningitis. Imaging (figure) revealed a neuroenteric fistula communicating with the thecal sac through a ventral sacral meningocele. This combination of anorectal malformation, sacral defect, and meningocele is known as the Currarino triad. ${ }^{1,2}$ Early recognition of this entity is of paramount importance in preventing a potentially devastating meningitis.

Tom Theys, MD, Kuan H. Kho, MD, Bart Nuttin, MD, PhD, Leuven, Belgium

Disclosure: The authors report no disclosures.

Address correspondence and reprint requests to Dr. Tom Theys, Department of Neurosurgery, University Hospitals Leuven, Herestraat 49, 3000 Leuven,Belgium; tom.theys@uz.kuleuven.be

1. Currarino G, Coln D, Votteler T. Triad of anorectal, sacral, and presacral anomalies. AJR Am J Roentgenol 1981;137: 395-398.

2. O'Riordain DS, O'Connell PR, Kirwan WO. Hereditary sacral agenesis with presacral mass and anorectal stenosis: the Currarino triad. Br J Surg 1991;78:536-538. 


\title{
Neurology
}

\author{
$A$ vaginal CSF leak \\ Tom Theys, Kuan H. Kho and Bart Nuttin \\ Neurology 2009;72;1446 \\ DOI 10.1212/WNL.0b013e3181a18890
}

\section{This information is current as of April 20, 2009}

\section{Updated Information \& Services}

\section{References}

Subspecialty Collections

Permissions \& Licensing

Reprints including high resolution figures, can be found at: http://n.neurology.org/content/72/16/1446.full

This article cites 2 articles, 0 of which you can access for free at: http://n.neurology.org/content/72/16/1446.full\#ref-list-1

This article, along with others on similar topics, appears in the following collection(s):

All Clinical Neurology

http://n.neurology.org/cgi/collection/all_clinical_neurology

Cerebrospinal Fluid

http://n.neurology.org/cgi/collection/cerebrospinal_fluid

Critical care

http://n.neurology.org/cgi/collection/critical_care

Meningitis

http://n.neurology.org/cgi/collection/meningitis

Information about reproducing this article in parts (figures,tables) or in its entirety can be found online at:

http://www.neurology.org/about/about_the_journal\#permissions

Information about ordering reprints can be found online:

http://n.neurology.org/subscribers/advertise

Neurology ${ }^{\circledR}$ is the official journal of the American Academy of Neurology. Published continuously since 1951, it is now a weekly with 48 issues per year. Copyright . All rights reserved. Print ISSN: 0028-3878. Online ISSN: 1526-632X.

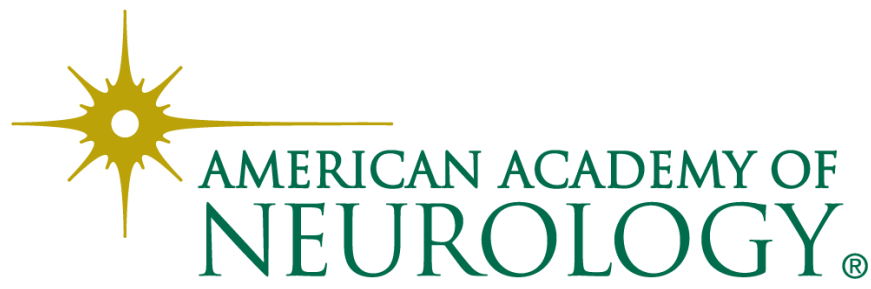

